\title{
COMMERCIAL REAL ESTATE \\ LOANS - CATEGORIZATION OF AN INVESTMENT SEGMENT
}

\author{
Beate Monika Philipps ${ }^{1}$ \\ ${ }^{1}$ Mendel University in Brno, Czech Republic
}

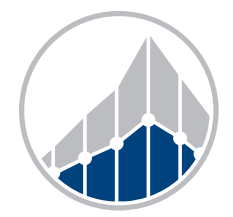

EUROPEAN JOURNAL OF BUSINESS SCIENCE AND TECHNOLOGY

Volume 7 Issue 1

ISSN 2694-7161

www.ejobsat.com

\begin{abstract}
Commercial real estate loans (CREL) are a modern essential business segment and of major relevance to the financial stability of an economy as they interconnect the financial markets and the real economy. Consequently, CREL are of specific interest to regulatory authorities. As far as the author knows, there exists no universal definition of CREL in the global financial industry and the regulatory environment. This has been subject to criticism due to resulting gaps and bias in data generated by regulatory filing. This study contributes to academia and applied sciences by providing the missing link. It develops a comprehensive categorization of CREL on a foundation of 34 sources predominately provided by regulatory authorities in the US and the EU. The categorization is based on a qualitative synthesis of main CREL characteristics of this particular heterogeneous asset class outlined in the detected sources. The objective of this work is to support the development of a common understanding of this investment segment among banks, institutional investors and regulatory authorities in order to allow an accurate and prompt filing.
\end{abstract}

\section{KEY WORDS}

financial economics, commercial real estate loans, investment decision, risk management

\section{JEL CODES}

G21, G32, G110, R33

\section{INTRODUCTION}

Commercial real estate ( $\mathrm{CRE}$ ) lending is intertwined with the financial economy through financial intermediaries like banks, insurance companies or CMBS lenders (Glancy et al., 2019). A downturn of the CRE markets might affect the financial industry through losses from CRE lending and spread into the real economy. As evidenced from existing empirical research, CRE markets tend to be volatile and are correlated to the economic cycle. In addition, a 
decline of CRE values might lead to a decrease of CREL funds provided by lenders (ECB Review, 2007) and shorten the loan supply necessary for new real estate investments. In this context, CRE finance is of specific interest to the regulatory authorities. One of the main features that separates CREL from other loan types like consumer loans, commercial and industrial loans (C\&I loans), or residential real estate loans (RREL) is the linkage to the CRE that may serve as security for the loan (OCC Handbook, 2013; Glancy et al., 2019; Phillips, 2009). The commercial property represents simultaneously the collateral and the primary source of repayment of the loan which is generated by rental income or sale proceeds (Federal Register, 2006). Corporate loans in contrary, even if they are secured by a mortgage on a property, do not qualify as CREL because their repayment source is funded by the borrower's operational business (OCC, BOG, FDIC Sound RM Practices, 2006). According to FDIC's homepage ${ }^{1}$, CRE lending includes the "acquisition, development, and construction (ADC) financing and the financing of incomeproducing real estate" that is leased to third parties. The investment segment CREL is noticeably heterogeneous and its characteristics are multidimensional. There is, to this author's knowledge, per se no common definition for this investment segment in place despite the CREL market being globally linked. Bassett and Marsh (2017) outline the necessity for a joint understanding of CRE between regulators and banks in order to generate an accurate data base, for instance to identify concentrations of CREL. The global financial crises of 2008 that was triggered by a downturn of the US real estate market is a perfect example that an accurate data base and prompt reporting is essential. The FDIC Financial Institution Letter (2008) that was issued on March 17, 2008, only 6 months prior to Lehman Brothers Holding Inc.'s filing for bankruptcy protection, illustrates that the FDIC had identified a deterioration of the CRE market that threatened banks with high CREL concentrations. The
FDIC's recommendation to combat the risk had been too late for some of the institutions to encounter the hazard. This reveals that a common categorization of CREL is of utmost importance for regulatory authorities, banks, and the real estate industry.

The missing comprehensive definition is the identified white spot and the key motivation for this study. This work contributes to academia and applied sciences by establishing a categorization of CREL with the goal of supporting the supervisory authorities' ability to analyze and evaluate their member institutions' CREL risk patterns. Their assessment may then be based on accurate and prompt data processing and regulatory filing provided by the lenders. In addition, this study shall support to develop a common understanding of this asset class for the financial industry and regulatory authorities.

First, this paper identifies the main characteristics of CREL. Second, it outlines the risks that are involved in this asset class in order to develop a universal understanding of CREL. Third, it establishes a categorization of CREL based on the predominant loan characteristics and the inherent credit risk which is closely linked to the CRE market. Recommended classifications within the categorization reflect the various CREL types subdivided upon their risk hierarchy. According to Jacob (2004), a categorization is a composition of groupings that display similarities based on context or perception. A classification, in contrast, outlines the relation and hierarchy within the grouping. The borders of a categorization are permeable and leave room for further perceived similarities (Jacob, 2004).

The remainder of this paper is organized as follows. Section 2 covers the various information sources that were utilized. Section 3 is dedicated to the identification of the main characteristics of CREL and outlines the various risks that are involved in CRE lending. Section 4 contributes by way of qualitative synthesis in order to categorize CREL. Section 5 concludes with a final recapitulation.

\footnotetext{
${ }^{1}$ FDIC Banker Resource Center. For details, please visit https://www.fdic.gov/resources/bankers/credit/ commercial-real-estate-lending/.
} 


\section{INFORMATION SOURCES}

According to Pana (2010), supervisory authorities have a strong impact on the lending policies and the risk management of financial institutions. Significant CREL providers are banks and insurance companies, both regulated institutions. For this reason, records of supervisory authorities with the main focus on the US and the EU were employed for the review. The US and the EU represent major CRE and financial markets. In addition to regulatory sources, scientific articles from electronic data providers were employed to complement the review.

Essential US depository regulators include the Federal Reserve (Fed), represented by the Board of Governors (BoG) and 12 regional reserve banks, the Office of the Comptroller of the Currency (OCC), the Federal Deposit Insurance Corporation (FDIC) and the National Credit Union Administration (NCUA). Astonishingly, US insurance companies are regulated on a state level and not by federal agencies. The National Association of Insurance Commissioners (NAIC) serves as unifying and coordination entity (Labonte, 2020). The financial supervision on EU level is represented through the European Banking Authority (EBA), the European Securities and Market Authorities (ESMA), and the European Insurance and Occupational Pensions Authority (EIOPA). The European Systemic Risk Board (ESRB) is affiliated to the ECB and is supplementing the three authorities. The Federal Financial Supervisory Authority (BaFin) is supervising German financial institutions on the national level.

Systematically all homepages of the aforementioned supervisory authorities have been assessed by using the keywords "commercial real estate lending" and "commercial mortgages". Throughout the initial screening process 33 relevant sources were detected, 23 sources thereof were assigned to the US regulation. The remaining ten sources belong to the EU regulation. If identical records by different regulatory providers of one country were identified, only one source was assigned to the review set. 11 sources were found in the electronic data providers Google Scholar, Science Direct,
Scopus, Springer, and Core. Ten papers thereof were published in scientific journals, one source represents a white paper by the staff of BoG. The majority of documents have been published between the years 2003 and 2020. Ten documents of the original set of 44 identified sources have been excluded as they either provided no additional insight or were irrelevant in the context of CREL. The review was therefore based on 34 records.

Utilizing the method of coding based on the Grounded Theory (Schreier, 2012), diverse components were detected, grouped and through qualitative synthesis re-arranged with the aim to categorize the asset segment CREL. A profile matrix was established for the coding process following Kuckartz (2014). The horizontal lines of the matrix pick up on the research questions and outline the essential headlines. Special attention has been paid to add adequate subcomponents during the second screening of the records. The different literature sources were stringed in vertical columns. The design of the profile matrix enables a subject-related overview of the thematic extracts (Kuckartz, 2014). The review of records included a ranking of the sources which connects to Okoli and Schabram's guidelines (2010). The records were divided into four classes. Laws and regulation were assigned to the premier quality class 1 , supervisory sources to level 2. Level 3 includes journals published in renowned journals. Further sources were labelled level 4. 23 identified sources, representing more than two-thirds of the records, were grouped into the category level 1 and 2 (legal sources), ten records were assigned to level 3 (excellent quality) and one source to level 4 (other).

This examination shall capture the main characterizing elements of CREL detected in literature and further data. It is beyond the scope of work to summarize all and each detail provided by the reviewed sources. This would diminish the purpose to give an overview of the major attributes of CREL. This review includes a critical evaluation of the researched literature as well as a qualitative synthesis with the aim to categorize CREL. 


\section{RESULTS}

\subsection{Predominant CREL Characteristics}

One of the main features that distinguishes CREL from other loan types is the underlying commercial real estate that serves as collateral for the loan. The Comptroller's Handbook (2013) and further sources of the Federal Deposit Insurance Corporation (FDIC), for example the Federal Register (1992), refer to CREL as a loan that is secured by a lien on or interest in real estate. Glancy et al. (2019) mention the security instrument commercial mortgage. Phillips (2009, p. 337) refers to real estate finance that is "almost universally secured by a mortgage". Blanket mortgages may cover multiple properties in cross-collateralization for one or multiple loans (Bardzik, 2019). The ESRB as well connects to CRE as collateral for a loan and refers in this context to corporate lending (ESRB Report, 2018). According to the Regulation (EU) 575/2013 (CRR) (2013) art 14, CREL is fully secured by the commercial property if the loan does not exceed the market value or, depending on the member state, the mortgage lending value. Robins et al. (2012) dig deeper in the fundamentals of the US mortgage law and outline that through a mortgage the lender receives an interest in the CRE as security for debt service and repayment of the loan. The Regulation (EU) 575/2013 (CRR) (2013) art 208 requires the mortgage or land charge to be enforceable at loan closing. In case the mortgagor, which in the vast majority - but not necessarily - is the borrower, does not perform according to its duty, the mortgagee has the right to foreclose on its lien on the property. The performance of borrower includes its payment duty as evidenced by the promissory note (Bardzik, 2019) or due to the loan agreement. This predominately includes the payment of debt service and the repayment of loan at maturity. Prior to a foreclosure an event of default remains uncured (Bardzik, 2019). Depending on the jurisdiction, the foreclosure includes a judicial or non-judicial sale of the property as remedy for the mortgagee's claims (Robins et al., 2012). Consequently, the value of the property is essential for the ultimate repayment of the loan. This aspect might be captured in the FDIC Financial Institution Letter (2009) recommending lenders to appraise the value of the underlying collateral if the decision of a loan workout shall be made. The Regulation (EU) 575/2013 (CRR) (2013) art 208 refers to commercial immovable property and requires banks to monitor the value of the CRE once a year. Depending on the country, the expression market value is legally defined. The Regulation (EU) 575/2013 (CRR) (2013) art 4 No 76 refers to the market value as the sales price on the evaluation date at which a willing purchaser buys an at arm's-length transaction from a willing seller. In the EU jurisdiction, Regulation (EU) 575/2013 (CRR) (2013) art 4 No 74, there exists another property value, the socalled mortgage lending value, which is defined as the future value of the property under the consideration of long-term sustainable rents under ordinary market conditions. As environmental hazard may cause huge damage to the commercial property which might result in a decrease of value, the FDIC has established its Guidelines for an Environmental Risk Program for its member institutions (FDIC Financial Institution Letter, 2006). The security of CREL does not necessarily depend solely on the CRE. Also, additional collateral may serve as loan protection. Federal Register (1992) depicts further real estate and unconditional, irrevocable standby letters of credit as additional security for CREL.

According to the Federal Register (2015), the institutions should take the nature of the underlying collateral into account. This term might refer to the property type of $C R E$ which is an outstanding characteristic of the collateral of CREL. The type of property includes several dimensions of CRE and it seems quite demanding to categorize this parameter. Supervisory authorities might consequently face challenges in their aim to select data from a common data base provided by banks or financial institutions. 
Predominantly, the property type refers to the use of the real estate. The Comptroller's Handbook (2013) identifies five primary real estate types that can also be identified in further sources: office buildings, retail properties, industrial properties, hospitality and multifamily residential real estate. These main CRE types might be sub-segmented. Retail properties have several specifications, among them shopping centers, strip malls, and department houses. Industrial properties, for instance, include manufacturing plants, warehouses or distribution facilities. Hospitality might include hotels and motels. The Regulation (EU) 575/2013 (CRR) (2013) art 126 (1) (a) includes offices or other commercial premises and art 128 (2) (d) hints at speculative immovable property that is according to (EU) 575/2013 (CRR) (2013) art 4 No 79 bought with the predominant aim to generate profit due to resale. The spectrum of CRE usage is broad and the Comptroller's Handbook (2013) serves as a detailed source that refers to assistedliving facilities, dormitories, residential health care and religious organization facilities as well. Case (2003) refers to single-purpose properties like assisted living or nursing homes. Mixeduse properties like retail, on the contrary, might be used for several purposes. This might be an advantage for the marketability of the premises. Within the second dimension of property type, income-producing property is segregated from real estate under construction or under development. Income-producing properties generate rent that primarily serves for the payment of debt service. This fact is even narrowed in the Federal Register (2006) as the guidance relates to properties where $50 \%$ or more rental income is generated from third parties that are non-affiliated with the borrowing entity. The OCC Handbook (2013) refers to nonowner-occupied property in this context and considers hospitals, golf-courses, car washes, and recreational facilities as owner-occupied if not rent to unaffiliated third parties. BoG, FDIC and OCC (2016) separate real estatesecured business loans when the real estate does not generate the repayment or debt coverage. The Regulation (EU) 575/2013 (CRR) (2013) art 402 (2) (d) also distinguishes between commercial immovable properties under construction and fully constructed. Johnston Ross and Shibut (2020) refer to a specific feature of CREL that is essential when segregating the property types into income-producing property and construction and development. They point out that the underlying $\mathrm{CRE}$ has not only the function to secure the loan. Rental income from the collateralized CRE is partially used for the payment of debt service. Properties under construction, however, do not generate rent. Their sale proceeds are used to repay the loan. This is the predominant pivotal point where the financial markets and the real economy are interconnected as the commercial property is the primary source of CREL repayment (Federal Register, 2006; Regulation (EU) 575/2013 (CRR), 2013). The interrelation between the CRE sector and the financial sector is derived from debt service payment and repayment of the CREL generated by rents and ultimately by sale proceeds of the CRE. In their risk management guidelines, the Board of Governors of the Federal Reserve System, Federal Deposit Insurance Corporation, and the Office of the Comptroller (Federal Register, 2006) point out that the cash flow of the property is the primary source of debt service coverage, whereas the loan exposure is covered by the value of property as the secondary source of repayment. Consequently, corporate loans, even if they are secured by a mortgage on a property, do not qualify as CREL as their repayment source is based on the borrower's operational business. The dimension property quality refers to specific quality metrics of $\mathrm{CRE}$ that might belong to the building substance, the tenant base, as well as the micro location of the property. In order to attract tenants, property owners have to increase their capital expenditures in the property or make rent concessions (Johnston Ross and Shibut, 2020). The OCC Handbook (2013) outlines three classifications of office buildings, varying from class A (high-quality) to class C (functional), depending on the quality of used construction material and quality of design and fixtures and their status of maintenance. The real estate industry often refers to land- 
mark buildings and trophy buildings as quality classification. Bardzik (2019) refers to quality with regard to the overall construction status of the building, the location, the occupancy rate, and the demand for the property in the market. BaFin refers to core real estate as fully leased properties with creditworthy tenancy base and tenancy structure in prime locations (BaFin Fachartikel, 2012). The cash flow of the property is as well determining the classification. Further risk classifications for real estate investments are core, core plus, value add, and opportunistic, depending on the degree of involved risk. During the recent years, building certifications in context with environmental social and governance (ESG) requirements of supervisory authorities have become more significant. Eichholtz et al. (2019) refer to LEED and Energy Star property certification systems in their examination. They show that the building certification has a positive impact on the cash flow of the building. Some countries in the EU, like the Netherlands, have already started to require a minimum environmental label in order to reserve the right to operate a building. Remarkably, CRE markets might be defined by property type. The various property types include corresponding risk intensities in response to economic downturns.

The Regulation (EU) 575/2013 (CRR) (2013) art 126 uses the term commercial immovable property for CRE which relates to an elemental feature of real estate. It is bound to its location and has to respond to changes of the environment. The evaluation of the property should include an extensive analysis of the location. The micro location describes the immediate surroundings of the property and its position within the immediate competitors. Each constellation is unique which supports the heterogeneous character of real estate (OCC Handbook, 2013; ESRB Report, 2018). The determining factors of the site analysis according to the OCC include the access of the property, the availability of public utilities, adjacent shopping utilities and further amenities, and possible future land development (OCC Handbook, 2013). Closeness to public utilities like schools or universities are positive aspects that increase the property value. Also, the vacancy rate of property compared to its competitors is important. Certainly, the evaluation of micro location should take the property type as well as competing neighboring real estate into consideration. The micro location requirements for large shopping malls, for instance, are completely different compared to multifamily estates. The macro location analysis responds to the broader economic environment of the property. Indicators for the economic developments are, among others, the employment rate and population trends including demographical developments (Federal Register, 1992). According to OCC, the demographic analysis should answer the question of household formation and household income (OCC Handbook, 2013). The OCC refers to the U.S. Census Bureau data provider in this context. Glancy et al. (2019) collect information on geography based on the zip codes of the properties. Some sources refer to location as geographic location, geographic market or geographic region (Federal Register, 2015; Federal Register, 2006; ESRB Report, 2018). Those terms are not defined but may be assigned to macro location. The Regulation (EU) 575/2013 (CRR) (2013) art 126 (2) (a) brings up macro-economic factors that may impact the value of the real estate. Case (2003) refers to the geographic region in terms of concentration risk. He illustrates that properties of the same region are likely to be impacted by similar economic factors. This seems to be coherent, but might depend on the property type. A distribution center might not respond as severely to negative regional economic changes, compared to an office building. Most sources do not distinguish between micro and macro location. Bardzik (2019) refers to location in general. The CRE markets can be defined in terms of micro and macro location as primary, secondary and tertiary markets (Bardzik, 2019). In relation to retail properties, the micro location classification might vary from $1 \mathrm{a}$ locations (most frequented micro location) to $2 \mathrm{~b}$ locations (mediocre frequented micro location, mixed use location). They include favorable site conditions, compared to $\mathrm{B}$ or even $\mathrm{C}$ locations. This connects to the risk classification 
core, core plus, value add, and opportunistic. The classification of macro locations reflects the criteria metropolitan area, urban aria and suburban area. Cities can be classified from A cities to D cities, depending on their economic significance to the region.

The value of the property is essential as it covers, in its function as collateral, the loan exposure. Especially at loan maturity it is an indicator for loan coverage (Bardzik, 2019). But as well throughout the loan term the property value is considered in the determination of the financial covenant loan to value (LTV). The property is usually evaluated by an independent appraiser that has the required knowledge (Federal Register, 1990). The market value is defined as the most likely property price in a regular market and at fair sale conditions under which the purchaser and seller maneuver in a far-sighted savvy manner (Federal Register, 1990). The FDIC Financial Institution Letter (2009) refers to the market value in the context of collateral valuation. The market value reflects the value at a certain point in time, it may change due to the market conditions (FDIC Financial Institution Letter, 2009). The FDIC refers to three basic valuation methods known as cost approach, direct sales comparison approach and income approach (FDIC RMS Section 3.2 Loans, 2020). For the evaluation of income-producing CRE the income approach is essential. Basically, it represents a discounted cash flow method to determine the net present value of the property. The value of income-producing real estate depends on the vacancy rate of the property, the lease renewal trends inclusive projected rents, discount rates, and direct capitalization rates (FDIC Financial Institution Letter, 2009). With regard to developments, the OCC refers to the market value on an as-is, as-completed or as-stabilized basis (OCC Handbook, 2013). The Regulation (EU) 575/2013 (CRR) (2013) art 229 (1) refers to valuation rules and to an independent appraiser to evaluate the market value. Unforeseen events like environmental hazard might negatively impact the property value and shall be taken into consideration in the assessment of the value (FDIC Financial
Institution Letter, 2006). Further explanation of the approaches is beyond the scope of this study. The BOG, FDIC and OCC (2015) refer to low capitalization rates and rising property values. The capitalization rate (cap rate) is the ratio between rental income and the value of the real estate. It reflects the profitability of the investment and the risk pattern of the CRE. The higher the cap rate, the higher the investment risk in the real estate market. The cap rate is an indicator of the CRE market condition for a defined property type but also a property value determinant. The Regulation (EU) 575/2013 (CRR) (2013) art 229 (1) refers to the mortgage lending value as a further value to appraise the property. This value is defined in Regulation (EU) 575/2013 (CRR) (2013) art 4 No 74. It shall be determined by a prudent assessment of the future marketability of the real estate based on long-term sustainable criteria of the property under regular market conditions. In Germany, for example, the mortgage lending value is based on the Pfandbrief Act and the Regulation on the Determination of the Mortgage Lending value (BelWertV). Usually, the mortgage lending value is a more conservative value compared to the market value.

Bardzik (2019) refers to the borrowers of CREL as corporate entities or private individuals. Usually in this loan segment, ring fenced special purpose vehicles (SPV) are the borrowing entities. Frequently, the borrower and the property owner are the same entity. An SPV's only function is to own and operate the collateralized property and this is usually of non-recourse to the sponsor. The sponsor is the managing and controlling entity of the borrower and the equity investor (Robins et al., 2012). Fig. 1 illustrates the sponsor - borrower relationship in connection with an SPV as mortgage borrower. The capital from the shareholders might be provided to the borrowing entity through shareholder loans which should be subordinated to the CREL by means of a subordination agreement (FDIC RMS Section 3.2 Loans, 2020). The non-liability of the sponsor is one reason according to the ESRB Report (2018) why CREL is relatively volatile 


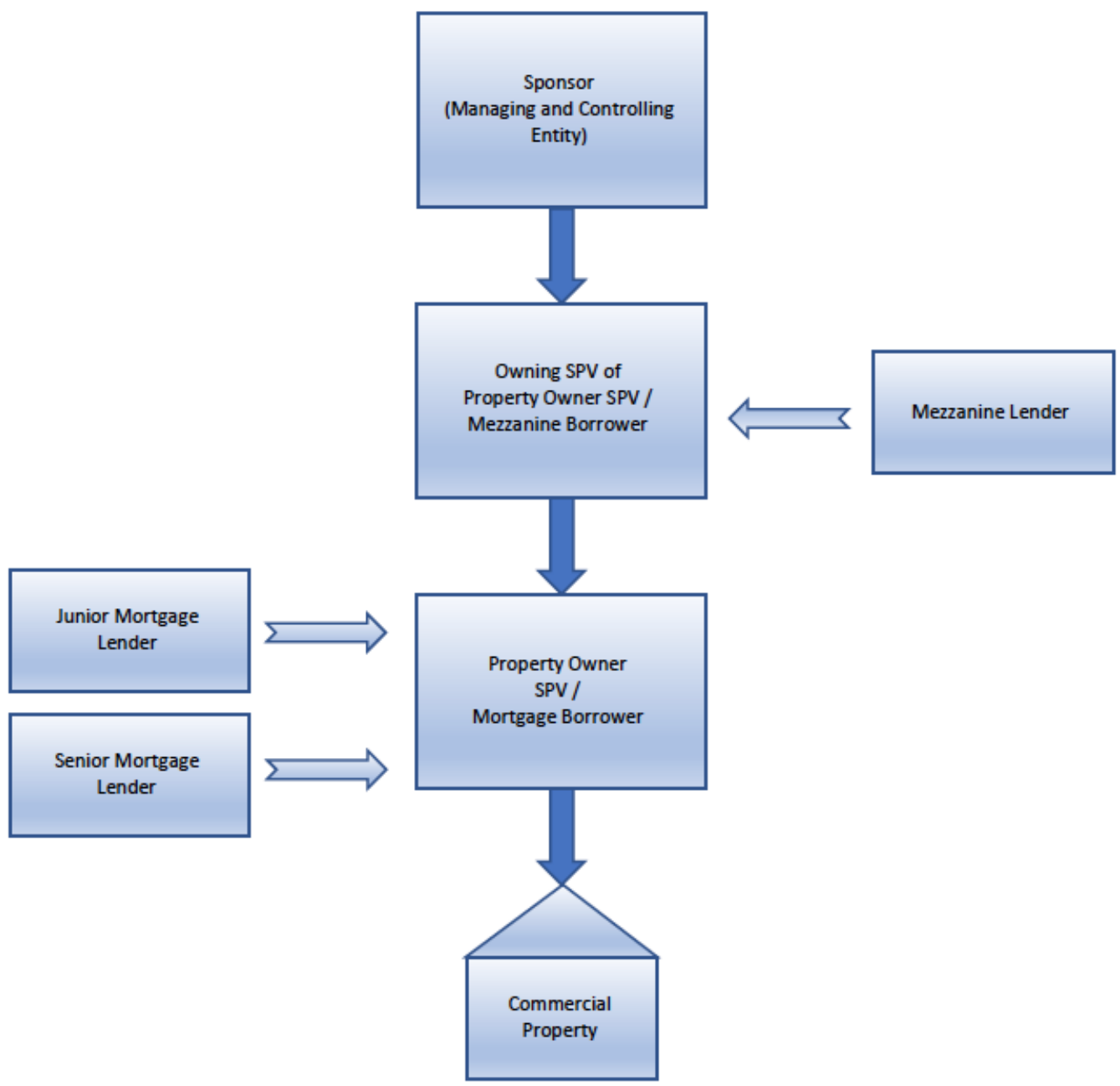

Fig. 1: Commercial Real Estate Ownership Structure with Senior Lender, Junior Lender, and Mezzanine Lender. Following Robins et al. (2012).

in comparison to RREL where the private individual's home represents the collateral. The sponsor, nonetheless, plays an important role for the success of the undertaking and asset management of the property. Special attention shall be paid to its track record and market standing. A sponsor might, depending on the risk profile of the CREL, provide a guarantee for the financing as additional collateral. In order to evaluate the guarantee, a lender shall consider the financial capacity of the guarantor and its ability to cover and repay its total indebtedness (FDIC Financial Institution Letter,
2009). Especially with regard to developments of CRE, the sponsor's capabilities to complete the project within the predetermined cost and time budget is essential (OCC Handbook, 2013). The Regulation (EU) 575/2013 (CRR) (2013) art 126 (2) ascribes to CREL a particular risk dimension, as the value of the property depends upon the credit quality of the borrower. The performance of the borrower as the owning SPV and the performance of the securing property to repay the CREL are unconditionally linked. The motivation for a borrower to engage in debt financing rather 
than to contribute in an equity investment, is based on the desire for diversification (Phillips, 2009). The so-called leverage effect plays a further dominant role. The return on equity might be increased employing debt financing. In case of portfolio financing, multiple borrower might be engaged. In this context it is important that each borrower is jointly liable and that a defaulting borrower, due to insolvency, is triggering a cross-default. Special attention within the risk monitoring shall be paid, if the borrower is an out-of-territory entity (FDIC Financial Institution Letter, 2015). In order to determine the utilization of borrower limits, the lenders shall identify the borrower's respectively the sponsor's aggregate exposure including derivatives (Federal Register, 2006).

\subsection{Broader CREL Characteristics}

CREL comprise specific loan structures. The maximum loan term should correspond with the type of property (Federal Register, 1992; OCC Handbook, 2013) and should not exceed the remaining useful life of the real estate. The OCC refers to CREL secured by income-producing multifamily properties with a longer loan term and hotel financing with a shorter term (OCC Handbook, 2013). Warehouse facilities represent a property type for an even compressed loan term due to their relatively short useful life span. The FDIC Financial Institution Letter (2009) and the Federal Register (2006) refer to the loan term and the structure of the loan. The OCC outlines a maximum term of 30 years, even if the property might have a longer useful life (OCC Handbook, 2013). The amortization schedule shall be in line with the loan term because the amortization protects against any diminishing collateral value during the loan term (OCC Handbook, 2013). Closely associated with the appropriate loan term is the tenancy structure. In case of a single tenant property, the lease expiration date should survive loan maturity by a determined timeframe in order to provide for a smooth loan exit. It is beneficial, if a part of the free cash flow is swept into a re-leasing and capital expenditure reserve to cover expenditures for refurbishment, rent concession, and rent-free periods. With regard to multi-tenant properties, the loan term might be linked to the weighted average lease term or the weighted average lease term to break option. If leasehold properties are involved, the loan term should expire at least ten years prior to the ground-lease expiration (OCC Handbook, 2013). Black et al. (2017) find that construction loans are short-term loans. Glancy (2019) shows that banks usually provide short-term loans whereas life insurers tend to lend long-term with more than ten years until maturity. Bardzik (2019) finds that commercial banks may provide shorter term loans based on underlying properties with less stable cash flows in contrast to life insurance companies. Ambrose et al. (2003) find that nonbank lenders that are not publicly traded or undergo a separate tax regime, like insurance companies, tend to be long-term lenders. Usually, the CREL is not completely paid off at maturity which requires a careful assessment of the property value to ensure loan exposure coverage at the end of the loan term (Bardzik, 2019). Johnston Ross and Shibut (2020) find that only $20 \%$ of the loan proceeds were repaid at maturity in their sample data of FDIC loans. This may have resulted from the sample date having included shorter-term bank loans. Black et al. (2017) find out that CMBS lenders provide in majority a loan term of ten years. Case (2003) finds that the average loan term for the financing of fully constructed properties amounts to five years and to one year for development and construction loans. The loan agreement may provide for termination rights or extension rights of the borrower. In case of early termination, the lender should make sure that a prepayment fee at-arms-length will be due to compensate for the lost interest portion respectively the reinvestment loss.

Loan term and amortization are closely interlinked. Both influence the loan structure (OCC Handbook, 2013). According to the Federal Register (2015), the borrower shall repay the loan in a timely manner. This might be done through graduate payments (Johnston Ross and Shibut, 2020) or annuity payments. As Bardzik (2019) states, each amortization 
reduces the loan exposure. The repayment of CREL might be recorded in an amortization schedule (Federal Register, 1992) which could include interest-only payment periods (BOG, FDIC and OCC, 2015). Ongoing amortization for CREL is generated by the rental income of the real estate securing the loan (FDIC Financial Institution Letter, 2015; Federal Register, 2006; Case, 2003). According to the Regulation (EU) 575/2013 (CRR) (2013) art 126 (2) (b), the repayment of CREL is derived from the performance of the underlying property. Pana (2010) describes this as main characterization of CREL. According to the OCC Handbook (2013), the amortization criteria is dependent on the loan type. Construction loans usually do not require ongoing amortization (OCC Handbook, 2013). They are usually repaid by sale proceeds of the project. OCC Handbook (2013) recommends to limit the interest-only periods until the cash flow from property is stabilized. Interest-only loan structures require a balloon payment at maturity (Johnston Ross and Shibut, 2010). Any re-amortization throughout the loan term increases the risk potential of the lender (OCC Handbook, 2013). The exit scenario relates to the ultimate payoff of the loan which might be accomplished through the refinance of the current lender or an alternative lender, through the sale of the property or, in a worst-case scenario, by foreclosure proceeds. The latter follows an event of default with acceleration of the loan (Bardzik, 2019). Mandatory repayments of the loan prior to maturity might be triggered through a sale of the property or the sale of shares in the borrowing entity that might be followed by a change of control. In case of portfolio financing, the loan documents might allow for partial repayment by sale proceeds from released units. The lender is advised to specify the allocated loan amounts for the sold units in order to maintain the quality of the remaining portfolio. During an ongoing event of default, proceeds from captured cash flow after debt service might be used to repay the loan amount. This usually follows an uncured cash trap or cash sweep event.

Traditionally, CREL are high loan volume transactions. The Federal Register, 2015 pushes the responsibility to the bank and points out that its loan procedure should take the loan amount into consideration. The loan approval process should consider the volume of the loan in connection to the property type and to the initial loan to value (LTV) as well as outlined in the supervisory maximum LTV limits of the Federal Register (1992). The Federal Register (2006) and the OCC Handbook (2013) pick up on these two determinants, too. In addition to these features, the lender shall consider the maximum loan amount per transaction and the maximum loan exposure of the borrower group in order to limited the maximum possible underwriting volume. Construction facilities usually include a budgeted interest reserve that increases the loan amount (FDIC Financial Institution Letter, 2009). This forces the borrower at the time of loan origination to fund the remaining necessary investment volume via equity or mezzanine loan proceeds. The loan documents should include cash trap or cash sweep mechanism to force borrower to partially repay the loan amount in case of non-compliance with the LTV covenant during the loan term. Glancy et al. (2019) find that CMBS transactions exceed portfolio lender loan amounts by $200 \%$ on average. Black et al. (2017) call up on this fact as well. Wong and Kaminski (2019) find that the loan volume per transaction of life insurance companies is usually higher compared to loan amounts provided by property and casualty insurances. It is common in the CREL industry, that a club of lenders is providing a high-volume loan. Club deals or participations are types of loan syndication.

Basically, the CRE loan type may be classified according to the usage of the loan proceeds, the purpose of the loan, as well as the degree of borrower's liability. Following this rationale, CREL can be classified as land development loans (Federal Register, 2006; Pana, 2010), commercial construction or development loans (Federal Register, 2006; FDIC RMS Section 3.2 Loans, 2020; Johnston Ross and Shibut, 2010), and acquisition loans. In the case where the loan proceeds are allotted to the improvement of the property (BOG, FDIC and OCC, 2015), 
the classification includes refurbishment loans. The acronym ADC includes acquisition, development and construction loans (FDIC Financial Institution Letter, 1998; OCC Handbook, 2013). The OCC Handbook (2013) further relates to bridge loans to cover the shortterm period of rental income stabilization of the property and to bridge the time slot until the refinancing of the loan. The refinance of CRE is the replacement of an existing mortgage with a new loan. Depending on the individual circumstance, the total loan amount might be divided into several tranches, such as an acquisition tranche and a capital expenditure tranche. The capital expenditure advances shall be used to improve the property quality and might increase the chance of successful releasing in case of value-add properties. The loan proceeds might not be necessarily invested in the underlying property but may be used for other purposes. Depending on the degree of borrower's liability, CREL are non-recourse loans, recourse loans or partially recourse loans (Federal Register, 1992). Frequently, CREL are provided to non-recourse ring-fenced borrower structures due to sponsor liability protection but as well to shelter the lender from any crossdefault within the sponsor entity structure. With regard to the loan risk evaluation of the supervisory authorities, CREL may be classified as substandard, doubtful, loss, and special mention depending on borrower's capability of repayment (FDIC RMS Section 3.2 Loans, 2020; FDIC Financial Institution Letter, 2009). Depending on the ability to repay the loan, CREL may be assigned to performing loans and non-performing loans.

An important feature of the CRE loan structure is the lender's contractual ranking of security position. The ranking classifies the loss absorption in case of a foreclosure (Robins et al., 2012). CREL might be structured with regard to the risk profile of the lender (OCC Handbook, 2013). There might be senior loans and junior loans in place depending on the ranking of the lien on the property, also referred to as first lien and second lien (OCC Handbook, 2013). Bardzik (2019) refers to subordinate ranking in connection with second and third mortgages. Depending on the lender's risk appetite, the structuring of a senior and a junior portion might be obsolete and the lender might finance the so-called whole loan. In case of a restructuring of a loan, the inclusion of first and subordinate liens might be reasonable in order to distinguish between performing and non-performing tranches (FDIC Financial Institution Letter, 2009). Mezzanine loans are often referred to in connection with CREL. But in contrast to CREL they are secured by a pledge of ownership interest in the property owner and not by a mortgage on the property (Bardzik, 2019). Upon foreclose in the company shares, the mezzanine lender might bid and ultimately become the indirect owner of the property. Mezzanine loans include an in place structural subordination to senior and junior loans (Robins et al., 2012). Therefore, they provide a higher risk component compared to CREL but represent a lower risk in comparison to equity (Phillips, 2009). Fig. 1 displays the specific loan relationships including senior/junior finance and mezzanine finance in an SPV structure.

Of utmost significance are the loan documents of CRE finance as the loan agreement and the accompanying finance documents establish the contractual frame for the relationship between lender and borrower throughout the whole loan term. As expressively pointed out in the Federal Register (2015), the lender shall make sure that its legally valid loan claim is enforceable. According to FDIC Financial Institution Letter (2006), the loan agreement should as well protect the lender against any environmental liability in connection with the contamination of the property. Also, loan purchase and participation agreements that concern the relation of lenders amongst each other are of high relevance (FDIC Financial Institution Letter, 2015). It is important that voting and enforcement rights within the lender group should be addressed as well. Additionally, the right to sell the loan participation should be included (FDIC Financial Institution Letter, 2015). Intercreditor agreements rule the relationship among the lenders with differing ranking, especially the relationship between mortgage lenders and 
mezzanine lenders (Robins et al., 2012). The lender may mandate an external legal advisor for the review of the participation agreement and especially for high volume CRE finance documents (FDIC Financial Institution Letter, 2015). A certain degree of standardization with regard to the loan documentation is beneficial to maintain the fungibility of the CREL and to keep the loan transaction costs low. The standardization of loan documents is evidenced by CMBS transactions that are usually less complex than loan documents used in portfolio transactions (Robins et al., 2012). The loan market association standard (LMA) for loan agreements is also well known in the industry. One disadvantage of standardized finance documents is, that they do not provide space for flexibility, for instance during times of special situations. This is where portfolio lenders generate a comparative advantage using non-standardized loan agreements (Black et al., 2017).

The interest rate structure of CREL ranges between fixed and adjustable rates (FDIC RMS Section 3.8 Off-Balance Sheet Activities, 2019; Federal Register, 2006). Life insurers and CMBS lenders tend to arrange fixed rates with the borrower, banks usually provide floating rate loans (Glancy et al., 2019; Black et al., 2017). Pricing components like commitment fees, upfront fees, and agency fees impact the price structure of CREL. The interest rate shall bear the cost of loan funding, loan administration and credit risk. The interest rate should as well compensate illiquidity cost since CREL are a rather illiquid asset class with only a secondary market in place. The profit/risk profile shall also take the type of the underlying property into consideration (Federal Register, 1992). Compared to office buildings, leisure accommodation and hotels represent higher risk as those property types quickly respond to economic downturns. Therefore, they demand a higher pricing (Glancy et al., 2019). The recent changes in the perception of the financial industry of environmental sustainability and ESG performance might have an impact on future pricing of CREL. A first approach in this context has been included in the BaFin Guidance (2020).
The cash flow generated by rental income or sale proceeds deducted by operating costs of the underlying property impacts the structure of the loan. Johnston Ross and Shibut (2020) point out that CREL are structured with regard to lease payment schedules. The Regulation (EU) 575/2013 (CRR) (2013) art 126 (2) explicitly relates to the cash flow generated by the underlying property. Pana (2010) refers to the cash flow as main source of repayment of CREL. The cash flow shall grant the appropriate debt service coverage at all times during the loan term and the repayment of the loan (BOG, FDIC and OCC, 2015). Certainly, a long-term predictable cash flow is beneficial for CMBS transactions (Black et al., 2017). The cash flow analysis is the pivotal element in the evaluation of CREL and based, among others, on the lease agreements. The cash flow projections should account for appropriate vacancy rates and adequate re-leasing periods (OCC Handbook, 2013). The analysis should as well take rent increases (Bardzik, 2019) and indexed rents into consideration. In the case of insufficient cash flow in combination with shortage of reserves or equity, the borrower might take third party capital providers into consideration (Robins et al., 2012). Eichholtz et al. (2019) find that environmentally certified buildings might account for a constant cash flow and reduce consequently the risk of CREL.

CREL might include loan covenants in the loan documentation that may impact the loan quality. Financial covenants may bridge the information gap between borrower and lender and might reduce lenders' risk. The LTV or the modified version loan to mortgage lending value (LTMLV) belong to the capital covenants. The LTV represents a limit for the maximum loan amount $L$. Tight senior loan LTV-limits require higher borrower equity or third-party contributions (Robins et al., 2012). According to the Federal Regulation (1992), the maximum supervisory LTVs are connected to the underlying property type. The loan amount shall not excess a certain threshold of the property market value $V$ (Cremer, 2019), all senior liens shall be taken into consideration (OCC Handbook, 2013). Some German banks 
prefer to focus on the LTMLV as defined in the Regulation on the Determination of the Mortgage Lending Value (BelWertV) instead of the market value as it reflects a conservative sustainable property value. Glancy et al. (2019) examine the LTV limits by lender type and discover that banks even provide loans above $75 \%$ LTV, life insurers generally offer loans within the range of $50 \%$ to $67 \%$ LTV and CMBS lenders from $60 \%$ to $71 \%$ LTV. Equation (1) reflects the LTV ratio.

$$
\mathrm{LTV}=\frac{L}{V}
$$

The performance covenant yield on debt (YoD) exposes the property cash flow $C_{t}$ relative to the loan amount $L_{t}$ at a defined point in time. This reflects the ability of property's cash flow to cover indebtedness. Equation (2) outlines the YoD ratio.

$$
\mathrm{YoD}_{t}=\frac{C_{t}}{L_{t}}
$$

The debt service covenant (DSCR) or interest service covenant (ICR), belong to the performance covenants as well. The DSCR is the key indicator to measure the debt coverage capability of the property's net operating income (NOI). $\mathrm{DSCR}_{t}$ depicts to what extend the debt service for a loan amount $L_{t}$ is covered by cash flow $C_{t}$ or by $\mathrm{NOI}_{t}$ of the property (Cremer, 2019; OCC Handbook, 2013). Lenders determine a DSCR covenant depending on the risk grid of the underlying property. As an example, the DSCR covenant for a loan secured by an office building might be lower compared to a DSCR of a hotel financing. Glancy et al. (2019) detect the typical DSCR at 1.50, for hotel financing at 1.85 . The DSCR covenant is outlined in equation (3).

$$
\operatorname{DSCR}_{t}=\frac{C_{t}}{L_{t}}
$$

The ICR is an alteration of the DSCR covenant and a "second line of defense" (Cremer, 2019, p. 378) outlining coverage in case of deferral of amortization or in case of bullet loan structures. There exist further covenants like guarantor financial requirements or requirements of minimum borrower equity. LTV and
DSCR should not be a static reflection at loan origination but should be calculated on an ongoing basis during loan term (Bardzik, 2019). Non-compliance with financial covenants might lead to an event of default and ultimately to the acceleration of loan and the foreclosure.

Typical CREL lenders are commercial banks, life insurance companies and CMBS lenders (Glancy et al., 2019; Bardzik, 2019). The ECB Review (2007) further includes pension funds as CRE debt investors but not as immediate CREL lender. According to BaFin, banks might withdraw from the CREL market due to high capital charges in respect to Basel III and insurers might bridge the resulting financing gap (BaFin Fachartikel, 2012). Commercial banks perform in their function as loan originator and balance sheet lender and benefit from the immediate borrower relationship (Downs and $\mathrm{Xu}, 2015)$. CMBS lenders, on contrary, have almost no deeper relationship to the borrower (Downs and $\mathrm{Xu}, 2015$ ). The lender strategy might focus on a loan sale right after origination without recourse to the purchaser (Federal Register, 1992). Especially after the excessive loan sales experienced during the global financial crisis 2008, this type of business might be currently rather limited. Some institutions, especially those without direct relationships to potential CRE customers, implement loan participations in their business model. The main drivers for this business strategy are fast CREL exposure increase and the diversification of risk and profitability (FDIC Financial Institution Letter, 2015). For the selling institutions risk diversification is a benefit as well. In addition, exhausted borrower limits might get released in order to provide leeway to originate new business with the CREL borrower (FDIC RMS Section 3.2 Loans, 2020).

\subsection{CREL Inherent Risks}

According to the OCC Handbook (2013), CRE lending might be accompanied by seven risk categories. These comprise the credit risk, interest rate risk, liquidity risk, operational risk, compliance risk, strategic risk, and reputation 
risk. The various risk types may be in place simultaneously. They may as well interrelate and interconnect.

The underlying CRE might serve as collateral and debt service provider for the CREL and in this respect could be considered as a two lines of defense system (Kim, 2013; Johnston Ross and Shibut, 2020). The CRE markets are essential risk drivers of CREL as rents impact the cash flow of a property and its value. Prospering CRE markets depend on an intact legal, economic and political system. These attributes as well define a performing debt market (Phillips, 2009). The OCC refers to the CRE markets as the "key elements of risk" of CRE finance (OCC Handbook, 2013, p. 1). The CRE markets are correlated to the real economy (Black et al., 2017) and thus respond to local and national economic developments (OCC Handbook, 2013). As outlined in the Statement on Prudent Risk Management for Commercial Real Estate Lending rents, sale prices, and operating expenses impact the repayment and debt service coverage of the loans (BoG, FDIC and OCC, 2015). According to the Federal Register (2015), the lenders shall analyze the respective market of the underlying CRE. The Federal Register (1992) recommends a market condition monitoring in order to adequately respond to market changes. According to the Federal Register (1990) abnormal market developments shall be explicitly outlined in an appraisal. Those market developments could be caused due to excessive price increases of certain CRE that follow the strong demand of investors in a defined risk bucket (BaFin Fachartikel, 2012). The turning of CRE markets with asset price deterioration or increasing vacancies could cause non-compliance with contractual LTV covenants or, in the worst case, unsecured loan exposures and uncovered debt service. The FDIC Financial Institution Letter (2008) recommends to request from borrower current cash flow statements and rent schedules. It might be necessary for the lender to mandate a revised appraisal in case of deteriorating CRE market conditions in order to re-evaluate CREL collateral (FDIC Financial Institution Letter, 2008). This emphasizes the linkage between the
CRE markets and the CREL inherent credit risk. Once CREL defaults become systemic, they may infect the financial economy and ultimately harm the real economy (ESRB Report, 2018). A CRE market bubble might be inflated as a result of a long-term low yield environment (ESRB Report, 2018) caused by investor's high demand of additional alpha. Signs for a turning CRE market might be the increase of rent concessions, substantial amendments to construction and development projects inclusive construction delay, prolonged re-leasing of rental space and slow unit sale (FDIC RMS Section 3.2 Loans, 2020). Excessive property development activities with vast increase of supply of CRE space might affect the CRE markets negatively (FDIC Financial Institution Letter, 1998). Cheap loan supply and extensive lending could even boost CRE market developments but also cause an immediate market drop if the loan supply runs dry (Bassett and Marsh, 2017). Property types might respond to economic changes differently (OCC Handbook, 2013). The hotel sector may be intensely linked to the development of wages and the unemployment rate. The success of construction projects depends on the accurate timing within the economic cycle and the demand of the market participants. According to the OCC Handbook (2013), construction projects respond extremely sensitive to the economy. As Case (2003) points out, supervisory authorities, as the Federal Reserve Board, deem construction loans as highly sensitive to downturns of the CRE markets. To mitigate the risk, lenders should insist on adequate pre-leasing or pre-sales. Important economic indicators for CRE markets are demographic changes, the development of income and of the unemployment rate (OCC Handbook, 2013). Changes to existing laws like rent control or condominium conversion rules, could strongly impact the CRE market condition (OCC Handbook, 2013). Both, lender and borrower might be hit by a CRE market downturn. However, they might be affected with different severity. Depending on the LTV of the financing, the lender might disproportionally participate in the investment compared to the borrower's 
equity contribution. Notwithstanding this fact, borrower's equity can be deemed as the first loss piece if the property value drops. The Directive 2009/138/EC (Solvency II) (2009) art 105 No 5 (c) refers to property risk in connection with "market prices of real estate". In addition, the Commission Delegated Regulation 2015/35 (Solvency II) (2014) art 174 reflects the CRE risk within the risk sub-module property risk. The ECB Review (2007) refers to the CRE market risk in connection with the potential of cross-border spreading of CRE price decreases.

The Federal Register (2015) refers to increased credit risk as the outcome of extensive lending. This risk is defined as the borrower's inability to repay its loan obligations. The Directive 2009/138/EC (Solvency II) (2009) art 13 defines credit risk as "the risk of loss or adverse change" of the counterparty's financial condition. The Regulation (EU) 575/2013 (CRR) (2013) mentions the terminology credit risk 263 times which emphasizes its significance to this regulation. A loss might occur if the loan exposure is not sufficiently covered by foreclosure proceeds of the underlying property or if the cash flow generated by the CRE does not cover the debt service during the loan term. According to the Federal Register (1990), the quality of a lender's collateral is influenced by the physical condition of the building. The lender shall pay special attention to the triangle of loan exposure, potential sale price of the property and the market demand for the type of property (FDIC RMS Section 3.2 Loans, 2020). Black et al. (2017) outline the property type as a predominant risk driver. According to the FDIC RMS Section 3.2 Loans (2020, p. 23), "adverse economic developments" could cause the lender to re-evaluate the credit risk. Construction delays might result in cost overruns (FDIC RMS Section 3.2 Loans, 2020) and threaten the completion of the project. Excessive and especially speculative property developments might negatively impact the existing properties in a sub-market, jeopardize their long-term financing, and ultimately lead to a loan quality deterioration (Bassett and Marsh, 2017). Usually, CREL are provided on a non-recourse basis without liability of the spon- sorship (ESRB Report, 2018). The Commission Delegated Regulation 2015/35 (Solvency II) (2014) art 42 (2) connects the credit risk to the defaulting counterparty and art 42 (5) explicitly states that the probability of Default (PD) of a borrower is related to its assets. The ECB refers to the credit risk as the main risk driver in CMBS transactions (ECB Review, 2007). Higher equity contributions of the sponsor, result in a lower LTV at origination, which might mitigate the credit risk. This shifts the risk from lender to the borrower and improves the risk sharing between lender and borrower (ESRB Report, 2018). The credit risk of distressed loans might be increased by asymmetric information distribution between lender and borrower, agency conflicts of securitized loans, contracting frictions in case of multiple lenders, and regulatory pressure (Downs and $\mathrm{Xu}, 2015$ ). According to FDIC Financial Institution Letter (2009), distressed loans are classified as substandard loans, doubtful loans, loss assets, and special mention. Loss assets are defined as loan exposures that are not covered by the market value of the property (FDIC Financial Institution Letter, 2009). If a loan is in distress, it is crucial to accelerate the decision, if a restructuring shall be processed or if the loan shall be foreclosed upon. Downs and Xu (2015) detect that portfolio lenders seem to resolve a special loan situation quickly compared to lenders of a securitization. They point out that balance sheet lenders, in contrast to CMBS lenders, are more likely to foreclose on a loan than to restructure the loan. The lender should not solely rely on the appraised value as the actual sales price of the property could differ (FDIC RMS Section 3.2 Loans, 2020). Inappropriate loan documentation might increase the credit risk (FDIC RMS Section 3.2 Loans, 2020). The risk measure expected loss (EL) might be used as a pricing component for CREL to compensate for the credit risk (Bardzik, 2019). The EL includes the PD, the loss given default (LGD) and exposure at default (EaD) as outlined in equation (4).

$$
\mathrm{EL}=\mathrm{PD} \cdot \mathrm{LDG} \cdot \mathrm{EaD}
$$


According to Kim (2013), the property cash flow has an impact on the PD whereas the LGD depends on the property value. Environmental property certification might positively influence the cash flow due to rent increases or short re-leasing periods (Eichholtz et al., 2019). Johnston Ross and Shibut (2020) are of the opinion that defaulting non-seasoned CREL are stronger impacted by economic turmoil and reveal higher LGDs compared to seasoned CREL. Increasing property values over time due to successful re-leasing or indexed rents might be the reason. The quality of a lender's loan portfolio might be classified by EL groups. Another signal of portfolio quality might be the extend of delinquencies (Pana, 2010).

The lender could be affected by the interest rate risk on its portfolio level. This risk might be hedged through derivatives like swaps (FDIC RMS Section 3.2 Loans, 2020). On transaction level, rising interest rates that are not accompanied by an increase of the property cash flow could cause a loan default (Phillips, 2009). The lender may push back this risk to the borrower and require borrower to enter into an interest rate hedging. Interest rate lock commitments counter borrower's interest rate risk during the loan approval process (FDIC RMS Section 3.2 Loans, 2020). The Regulation (EU) 575/2013 (CRR) (2013) addresses the terminology interest rate risk 21 times. The Commission Delegated Regulation 2015/35 (Solvency II) (2014) art 165 requires insurance undertakings to cover this risk with capital.

CREL are an illiquid asset class. The ECB Review (2007) refers to the underlying commercial property as illiquid. This emphasizes the fact that the liquidity risk of CREL is linked to the liquidity risk of the underlying asset. The liquidity risk is inherent during the entire loan term and especially at loan maturity as most of the CREL are not amortized during loan duration. The exit possibilities of CRE lending include the refinancing of the loan by a different lender, the securitization or the sale of the loan, and the full amortization throughout the loan term (OCC Handbook, 2013). The lack of fungibility of CREL represents the liquidity risk for the lender (Directive 2009/138/EC
(Solvency II) (2009) art 13 No 34). The Regulation (EU) 575/2013 (CRR) (2013) refers to the terminology liquidity risk nine times, much less in comparison to the reference to credit risk. The ESRB refers to this risk as lender's refinancing risk caused by a lack of liquidity to repay the loan at maturity (ESRB Report, 2018). Eichholtz et al. (2017) refer to the beneficial influence of environmental certified buildings as collateral on the cost of funds for the CRE financing. This mitigates the liquidity risk and might be an indicator for the quality of CREL. Environmental certification of the asset may reduce the liquidity risk during loan term and at maturity (Eichholtz et al., 2019). The Commission Delegated Regulation 2015/35 (Solvency II) (2014) art 326 requires the value of the asset of an SPV to be sufficient to cover the liquidity risk among others. The ECB refers to this risk bucket with regard to indirect investment products like speciality funds that do not have a primary market in place and therefore are less fungible (ECB Review, 2007).

BoG, FDIC and OCC (2015) refer to the operational risk as the risk that is inherent in a lender's internal processes and connected to lender's risk management. The FDIC Financial Institution Letter (2015) relates to this risk in context with lenders' activities in unfamiliar business segments or new markets. It is emphasized, that those segments and markets shall be comprehensively monitored and controlled. The OCC refers to strategic risk as a lender's risk of failure to effectively oversee the CRE lending activities which could lead to a non-compliance with the lender's CRE lending policy (OCC Handbook, 2013). This risk per definition could also be assigned to the operational risk bucket. A significant amount of defaulting loans might cause banks to adjust their lending strategy which ultimately could result in restrictive lending. In the worst case, this might trigger a credit crunch and limit the real economy's new investments (ESRB Report, 2018). Supervisory requirements could as well affect the lender's strategy. Pana (2010) investigated changes in the strategies of banks prior to the global financial crisis. Pana showed that banks adjusted their strategy and 
shifted from CRE lending to RRE lending in order to decrease supervisory capital charges. The Regulation (EU) 575/2013 (CRR) (2013) mentions the terminology operational risk 53 times. The Directive 2009/138/EC (Solvency II) (2009) art 13 No 33 specifically defines this risk as risk resulting from internal processes that could also be triggered by external factors. The Commission Delegated Regulation 2015/35 (Solvency II) (2014) art 204 encloses the calculation of capital requirements for the operational risk. The ECB points out that this risk may be inherent in transactions of private equity funds and hedge funds (ECB Review, 2007). These investment groups usually are not regulated. They might not have sufficient internal processes and control systems in place.

Environmental issues like the contamination of the property do not only impact a lender's liability but may also account for a lender's reputation risk. The FDIC Financial Institution Letter (2006) require lenders to organize an adequate environmental risk assessment during the entire loan term. In general, the reputation of a lender could be negatively affected by lender liability lawsuit (OCC Handbook, 2013) or the negative influence of the borrowing entity or by a shady tenancy base. The Regulation (EU) 575/2013 (CRR) (2013) uses the terminology reputation damage only once. According to Directive 2009/138/EC (Solvency II) (2009) art 102 (4), this risk is allotted to the operational risk.

The OCC Handbook (2013) refers to compliance risk as the risk of non-compliance with laws and regulation, including environmental laws. The Regulation (EU) 575/2013 (CRR) (2013) does not refer to the term compliance risk at all. According to the Commission Delegated Regulation 2015/35 (Solvency II) (2014) art 270 (1), the undertaking shall set up a compliance management to encounter the compliance risk.

The Federal Register (1992) directly mentions the necessity for an institution to diversify its loan portfolio with respect to loan type, geographic market and loan quality in order to face the concentration risk. It is important that the lender takes the transaction loan amount and lender's entire CREL loan exposure into consideration. The concentration risk refers to a lender's portfolio cash flow correlation. The risk may be higher if the cash flows of a portfolio are positively correlated, which could be the case in connection with properties of the same macro location and similar economical exposure (Case, 2003). The Federal Register (2006) forces the supervised institutions to report in case their CREL exposure exceeds a defined threshold, such as construction loan threshold of $100 \%$ of the total capital of the institution or other CREL threshold of $300 \%$ of the total capital of the institution. The FDIC RMS Section 3.2 Loans (2020) includes the risk of the lender's loan exposure to a single entity or person. Some lenders have difficulties in diversifying their loan portfolio with regard to location or business segment as they are only active in limited local markets (FDIC RMS Section 3.2 Loans, 2020). According to BoG, FDIC and OCC (2015), the management board shall approve concentration limits within its risk management process. The Regulation (EU) $575 / 2013$ (CRR) (2013) mentions the terminology concentration risk ten times. According to the Directive 2009/138/EC (Solvency II) (2009) art 13 No 35, this risk could be severe and threaten the undertaking's going concern. The Commission Delegated Regulation 2015/35 (Solvency II) (2014) recital (62) refers to geographical or sector concentration of assets. According to Bardzik (2019), lender's CREL portfolio concentration may include LTV, YoD, DSCR, EL, PD, LGD segmentation in addition to property type and to the geographic area of the property. The diversification of asset classes and geographical markets creates a possibility to mitigate concentration risk. Pana (2010) fears that smaller banks might not encounter concentration risks fast enough to diversify their loan portfolio if necessary. This could be the case for local banks that provide CREL to borrowers in a limited geographical area. The ESRB also addresses the risk of concentration of losses and recommends cross-border syndication of CREL in order to mitigate the financing risk (ESRB Report, 2018). 


\section{DISCUSSION}

CREL are an essential investment segment in the economy which accounted in 2019 for 14\% of the US GDP (Glancy, 2019). Commercial banks, life insurance companies, and CMBS lenders are the main CREL providers (Glancy et al., 2019; OCC Handbook, 2013). As intermediaries, they clearly influence the capital flow into the real estate sector. Supervisory authorities extensively monitor the institutions' CREL activities as any deterioration in the financial market could infect the real economy. A synchronized and accurate database is essential for effective CREL supervisory monitoring, mainly because the asset class is particularly heterogeneous. Data gaps have been criticized especially by regulatory authorities (ESRB, 2018). With regard to the filing of the banks' CREL data base, time is of the essence. This was clearly evidenced by the experience made shortly prior to the global financial crisis of 2008 which was triggered by the deterioration of the US real estate market. Accordingly, the supervised institutions themselves might have an interest to fill this gap as their capital charges correlate with their risk weighted assets. Surprisingly, and as far to this author's knowledge, no universal definition of CREL exists in the global financial world. Only few articles of the reviewed set explicitly define this loan type, among them the Federal Register (2006) and Pana (2010). Although they provide a solid guidance, in some respect their definition might be misleading and ambiguous. The Federal Register (2006) basically ties CREL to the rental income generated by the underlying property as primary source of repayment and draws a second quantitative precondition. In the case where the borrower or an entity of the borrowing company group is providing $50 \%$ or more of the rental income, the criteria for CREL is not met. This is a notable approach to capture loans that are correlated to the CRE market risk. In this author's opinion, the threshold of $50 \%$ is rather high as consequently up to $49 \%$ of the rental income could be derived from the borrowing company group. This represents a risk sphere other than the CRE market. The risk of distortion of the tenancy schedule would shift from CRE market to the borrower's financial ability. Pana (2010) interconnects CREL to the cash flow from the property as well, but her definition does not include any threshold for third party rental income. She connects CREL to the usage of the loan for construction, land development, and other land loans. This list could have been completed by the acquisition of CRE, the refurbishment of the property, and the refinance of CREL. Pana (2010, p. 17) defines CRE among others as "multi-family residential properties". This gives room for interpretation. It is unclear if the term is based on the definition of multifamily property according to 12 CFR $\$ 1266.1$ which includes nursing homes, dormitories and homes for elderly. The Federal Register's definition (2006) takes land development loans, construction loans and land loans into account and explicitly includes 1-to-4 family residential construction and commercial construction. This would comprise one family residential construction which rather should be allotted to RREL. The definition includes as well multi-family and nonfarm nonresidential properties. It is beneficial, that loans to REITs and unsecured loans to developers are defined as CREL (Federal Register, 2006) as they are correlated to the CRE markets, too. Pana (2010) does not refer to these borrower groups at all.

In order to categorize CREL it is in this author's opinion important to focus on the main risk drivers of CREL and to understand how they impact the asset class. The general risk of providing loans is the inability of borrower to pay the debt service and ultimately, the risk of non-repayment of the loan obligation. This risk is defined by regulators as credit risk. The generated cash flow that provides for the debt service and the repayment of the loan is in focus. The Regulation (EU) 575/2013 (CRR) (2013) art 126 (2) (b) relates to exposures where the risk of repayment of the CREL is derived from the "performance" of the collateralized commercial property and is not generated by other sources. The Federal Register (2006) 

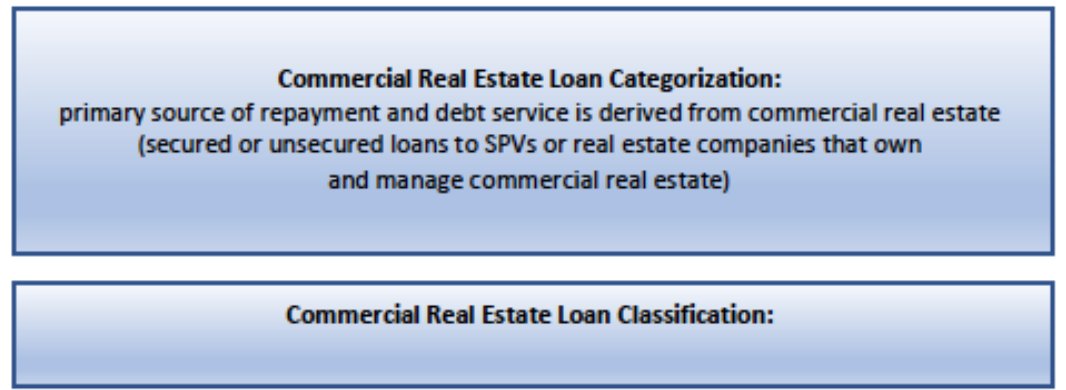

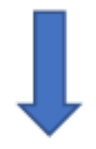

CREL secured by liens on or interest in the commercial property differentiated by security ranking (Senior CREL, Junior CREL)

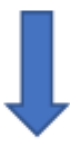

Non-mortgage-secured CREL to SPVs (Mezzanine Loans)

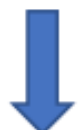

Non-mortgage-secured CREL to corporations (REITs or other real estate companies)

Fig. 2: Commercial Real Estate Loan Categorization and Classification

refers to the cash flow that is produced by CRE as a primary source of repayment. This excludes loans that are secured by CRE but where the primary source of repayment comes from the business operations that owns the property. It also excludes CRE where the borrowing entity is a tenant who exceeds a threshold of the tenancy base. The Federal Register (1992) interlinks the requirement to appraise a property by a State certified or licensed appraiser to those loans whose repayment depends on the sale or rental income as primary source. The BOG, FDIC and OCC (2015) deem the CRE cash flow analysis broken down to rents, sale proceeds and operating costs of extreme importance in order to evaluate the borrower's loan repayment ability. The OCC, in addition, outlines the significance to comprehend "the income generating capacity of real estate" (OCC Handbook, 2013, p. 36). Despite the rental income, sale proceeds of the CRE are essential for the repayment of the CREL, either generated through open sale or upon foreclosure on the loan. The value of the property is either determined by future rents or sale prices. The
Federal Register (2015) requires institutions to evaluate the value of collateralized properties. The Federal Register (1992) refers to the value of mortgaged CRE as main credit factor of the loan decision. The determination of market value is essential and for this reason it should be perfected by an independent appraiser (Federal Register, 1990). Cost approach, Direct Sales Comparison Approach and Income Approach are the main valuation concepts (FDIC RMS Section 3.2 Loans, 2020; BOG, FDIC and OCC, 2016). Their approach to evaluate the property interconnects with the evaluation of the CRE markets (BOG, FDIC and OCC, 2015).

Credit risk seems to be closely linked to the CRE markets. Following this rationale, CREL might be categorized as loans whose primary source of repayment and debt service is derived from CRE, either from rents or sales proceeds sourced mainly by non-borrower-affiliated third parties. The primary source of repayment might be derived from CRE that serves as collateral for the CREL. Secured or even unsecured loans to SPVs or real estate companies that own and manage CRE, like REITs, should be included 
as well in the categorization of CREL as their repayment is dependent on the development of the CRE markets. Classifications beneath the categorization might be established to differentiate among the various CREL risk characteristics. First, CREL might be classified as loans that are secured by liens or interest in the property depending on their security ranking. Second, CREL might be grouped in nonmortgage-secured loans to SPVs like mezzanine loans. Third, CREL might be clustered as nonmortgage-secured CREL to corporations, as REITs or other real estate companies. Fig. 2 exemplifies this categorization of CREL.
The developed categorization of CREL allows a broad approach on the one hand, and on the other hand captures different characteristics of this asset class. It separates CREL from further loan types like RREL where the risk is assigned to the value of the real estate as well, but where the cash flow is derived by other sources of the borrower, such as wages. The categorization separates CREL from corporate loans secured by properties where the cash flow that covers the debt service is generated by the operating business of borrower.

\section{CONCLUSION}

The aim of this work is to establish a categorization of CREL that is, to this author's knowledge, missing in the global financial sector. The developed categorization shall close the gap and provide a consistent structure of an extremely heterogeneous asset class. The classifications within the categorization of CREL shall set up a risk hierarchy and could support supervisory authorities' ability to analyze and evaluate the institutions' CREL risk pattern. A comprehensive CREL categorization might support lenders in their accurate and prompt data processing and regulatory filing. Additionally, this work shall assist in creating a common global understanding of this asset class between banks, institutional investors and regulatory authorities.

\section{ACKNOWLEDGEMENT}

We acknowledge the financial support of the Internal Grant Agency of the Mendel University in Brno, Grant No. 121106. The usual disclaimer applies.

\section{REFERENCES}

Ambrose, B. W., Benjamin, J. D. and Chinloy, P. 2003. Bank and Nonbank Lenders and the Commercial Mortgage Market. Journal of Real Estate Finance and Economics, 26 (1), 81-94. DOI: $10.1023 / \mathrm{A}: 1021574215894$.

BaFin Fachartikel. 2012. Versicherer: Immobilienkredite und realwirtschaftliche Anlagen werden attraktiver [online]. Available at: https://www.bafin.de/SharedDocs/ Veroeffentlichungen/DE/Fachartikel/2012/fa_ bj_2012_05_studie_versicherer.html. [Accessed 2020, November 18].
BaFin Guidance. 2020. BaFin Guidance Notice on Dealing with Sustainability Risks [online]. Available at: https://www.bafin.de/SharedDocs/ Veroeffentlichungen/EN/Meldung/2019/meldung_ 191220_MB_Nachhaltigkeitsrisiken_en.html. [Accessed 2020, November 18].

BARDzIK, S. J. 2019. Commercial Mortgage Loans [online]. NAIC \& The Center for Insurance Policy and Research. Capital Markets Bureau Primer. Available at: https: //www.naic.org/capital_markets_archive/ primer_190628_commercial_mortgage_loans.pdf. [Accessed 2020, October 18]. 
Bassett, W. F. and Marsh, W. B. 2017. Assessing Targeted Macroprudential Financial Regulation: The Case of the 2006 Commercial Real Estate Guidance for Banks. Journal of Financial Stability, 30 (C), 209-228. DOI: 10.1016/j.jfs.2016.06.001.

Black, L., Krainer, J. and Nichols, J. 2017. From Origination to Renegotiation: A Comparison of Portfolio and Securitized Commercial Real Estate Loans. The Journal of Real Estate Finance and Economics, 55 (1), 1-31. DOI: 10.1007/s11146016-9548-1.

BOG, FDIC and OCC 2015. Statement on Prudent Risk Management for Commercial Real Estate Lending [online]. Board of Governors of the Federal Reserve System, Federal Deposit Insurance Corporation, and the Office of the Comptroller of the Currency. Available at: https://www.federalreserve.gov/newsevents/ pressreleases/files/bcreg20151218a1.pdf. [Accessed 2020, October 18].

BOG, FDIC and OCC 2016. Interagency Advisory on Use of Evaluations in Real Estate-Related Financial Transactions [onlin]. Board of Governors of the Federal Reserve System, Federal Deposit Insurance Corporation, and the Office of the Comptroller of the Currency. Available at: https://www.occ.treas.gov/news-issuances/ bulletins/2016/bulletin-2016-8.html.

[Accessed 2020, November 13].

Case, B. 2003. Loss Characteristics of Commercial Real Estate Loan Portfolios [online]. A White Paper by the Staff of the Board of Governors of the Federal Reserve System. Available at: https://core.ac.uk/download/pdf/6608783.pdf. [Accessed 2020, November 20].

Commission Delegated Regulation (EU) 2015/35 (Solvency II). 2014. Official Journal of the European Union, L12, 1-797 [online]. Available at: https://eur-lex.europa.eu/legal-content/ EN/TXT/PDF/?uri=CELEX : 32015R0035\& rom=EN. [Accessed 2020, November 29].

Cremer, L. 2019. Underwriting Limits and Optimal Leverage in Commercial Real Estate. Journal of Real Estate Finance and Economics, 60 (3), 375-395. DOI: 10.1007/s11146-018-09695-4.

Directive 2009/138/EC of the European Parliament and of the Council (Solvency II). 2009. Official Journal of the European Union, L335, 1-155 [online]. Available at: https://eur-lex.europa.eu/legal-content/ EN/TXT/PDF/?uri=CELEX : 32009L0138\&from=EN. [Accessed 2020, November 29].

Downs, H. D. and XU, P. 2015. Commercial Real Estate, Distress and Financial Resolution: Portfolio Lending Versus Securitization. Real Estate Financial Economist, 51 (2), 254-287. DOI: $10.1007 /$ S11146-014-9471-2.
ECB Review. 2007. ECB Financial Stability Review December 2007 [online]. Available at: https://www.ecb.europa.eu/pub/pdf/ fsr/financialstabilityreview200712en.pdf. [Accessed 2020, November 18].

Eichholtz, P., Holtermans, R., Kok, N. and YöNDER, E. 2019. Environmental Performance and the Cost of Debt: Evidence from Commercial Mortgages and REIT Bonds. Journal of Banking \& Finance, 102, 19-32. DOI: $10.1016 /$ j.jbankfin.2019.02.015.

ESRB Report. 2018. Report on Vulnerabilities on the EU Commercial RE Sector [online]. ESRB European Systemic Risk Board. Available at: https://www.esrb.europa.eu/pub/pdf/ reports/esrb.report181126_vulnerabilities_ EU_commercial_real_estate_sector.en.pdf? 77 fdeb615a42bbf41dbf5a1dcfb053fc.

[Accessed 2020, November 19].

FDIC Financial Institution Letter. 1998. Acquisition, Development, and Construction Lending [online]. Available at: https://www.fdic.gov/news/ financial-institution-letters/1998/fil98110. html. [Accessed 2020, November 13].

FDIC Financial Institution Letter. 2006. Guidelines for An Environmental Risk Program [online]. Available at: https://www.fdic.gov/news/ financial-institution-letters/2006/ fil06098a.pdf. [Accessed 2020, November 13].

FDIC Financial Institution Letter. 2008. Managing Commercial Real Estate Concentrations in a Challenging Environment [online]. Available at: https://www.fdic.gov/news/ financial-institution-letters/2008/fil08022. pdf. [Accessed 2020, November 16].

FDIC Financial Institution Letter. 2009. Policy Statement on Prudent Commercial Real Estate Loan Workouts [online]. Available at: https://www . fdic.gov/news/financial-institution-letters/ 2009/fil09061a1.pdf.

[Accessed 2020, November 13].

FDIC Financial Institution Letter. 2015. FDIC Advisory on Effective Risk Management Practices for Purchased Loans and Purchased Loan Participations [online]. Available at: https://www. fdic.gov/news/financial-institution-letters/ 2015/fil15049a.pdf.

[Accessed 2020, November 13].

FDIC RMS Section 3.2 Loans. 2020. Risk Management Manual of Examination Policies of the FDIC, Part II, Section 3.2 Loans [online]. Available at: https://www.fdic.gov/regulations/safety/ manual/section3-2.pdf.

[Accessed 2020, November 13]. 
FDIC RMS Section 3.8 Off-Balance Sheet Activities. 2019. Risk Management Manual of Examination Policies of the FDIC, Part II, Section 3.8 Off-Balance Sheet Activities [online]. Available at: https://www.fdic.gov/regulations/safety/ manual/section3-8.pdf.

[Accessed 2020, November 13].

Federal Register. 1990. Part 323-Appraisals. Federal Register 55, No. 161: 33888-33890, August 20, 1990, as amended 2015.

Federal Register. 1992. Appendix A to Subpart A of Part 365 - Interagency Guidelines for Real Estate Lending Policies. Federal Register 57: 62896-62900, December 31, 1992, as amended 2013.

Federal Register. 2006. Concentration in Commercial Real Estate Lending, Sound Risk Management Practices. Final Joint Guidance. Federal Register 71, No. 238: 74584-74588, December 12, 2006.

Federal Register. 2015. Appendix A to Part 364 Interagency Guidelines Establishing Standards for Safety and Soundness. Federal Register 80, No. 208: 65908-65909, October 28, 2015, as amended 2018.

Glancy, D. P., Krainer, J., Kurtzman, R. J. and Nichols, J. B. 2019. Intermediary Segmentation in the Commercial Real Estate Market. Finance and Economic Discussion Series, Working Paper No. 2019-079. Washington: Board of Governors of the Federal Reserve System, 1-53. DOI: 10.17016/FEDS.2019.079.

JACOB, E. K. 2004. Classification and Categorization: A Difference that Makes a Difference [online]. Library Trends, 52 (3), 515-540. Available at: https://www.researchgate.net/publication/ 32956263_Classification_and_Categorization_ A_Difference_that_Makes_a_Difference.

[Accessed 2020, October 18].

Johnston Ross, E. and Shibut, L. 2020. Loss Given Default, Loan Seasoning and Financial Fragility: Evidence from Commercial Real Estate Loans at Failed Banks. Journal of Real Estate Finance and Economics. DOI: 10.1007/s11146-020-09783-4.

KIM, Y. 2013. Modeling of Commercial Real Estate Credit Risks. Quantitative Finance, 13 (12), 1977-1989. DOI: 10.1080/14697688.2011.592854.

Kuckartz, U. 2014. Qualitative Text Analysis. London: SAGE Publications. ISBN 978-1-4462-6774-5.

Labonte, M. 2020. Who Regulates Whom? An Overview of the U.S. Financial Regulatory Framework [online]. Congressional Research Service. Available at: https://fas.org/sgp/crs/misc/R44918.pdf. [Accessed 2020, October 25].

\section{AUTHOR'S ADDRESS}

Beate Monika Philipps, Department of Economics, Faculty of Business and Economics, Mendel University in Brno, Zemědělská 1, 61300 Brno, Czech Republic, e-mail: xphilipp@mendelu.cz
OCC, BOG, FDIC Sound RM Practices. 2006. Concentrations in Commercial Real Estate Lending, Sound Risk Management Practices [online]. Office of the Comptroller of the Currency, Board of Governors of the Federal Reserve System, Federal Deposit Insurance Corporation. Available at: https://www.federalreserve.gov/boarddocs/ srletters/2007/SR0701a2.pdf.

[Accessed 2020, December 1].

OCC Handbook. 2013. Commercial Real Estate Lending. Comptroller's Handbook [online]. Office of the Comptroller of the Currency. Washington, D.C. Available at: https: //www.occ.gov/publications-and-resources/ publications/comptrollers-handbook/ files/commercial-real-estate-lending/ index-commercial-real-estate-lending.html. [Accessed 2020, October 18].

Okoli, C. and Schabram, K. 2010. A Guide to Conducting a Systematic Literature Review of Information Systems Research. SSRN Electronic Journal. DOI: 10.2139/ssrn.1954824.

PanA, E. 2010. Commercial Real Estate Lending Concentrations: New Evidence. North American Journal of Finance and Banking Research, 4 (4), $13-24$.

Phillips, G. C. 2009. The Paradox of Commercial Real Estate Debt. Cornell International Law Journal, 42 (3), 335-360.

Regulation (EU) No 575/2013 of the European Parliament and of the Council (CRR). 2013. Official Journal of the European Union L176, 1-337 [online]. Available at: https://eur-lex.europa.eu/legal-content/ EN/TXT/PDF/?uri=CELEX : 32013R0575\&f rom=en.

Robins, J. S., Wallace, D. E. and Franke, M. 2012. Mezzanine Finance and Preferred Equity Investment in Commercial Real Estate: Security, Collateral \& Control [online]. Michigan Business $\&$ Entrepreneurial Law Review, 1 (1), 93-162. Available at: https://repository.law.umich.edu/cgi/ viewcontent. cgi? article $=1002 \&$ context $=$ mbel $r$ [Accessed 2020, November 27].

SchreIER, M. 2012. Qualitative Content Analysis in Practice. London: SAGE Publications. ISBN 978-1-84920-592-4.

Wong, M. and Kaminski, K. 2019. U.S. Insurers' Exposure to Retail Commercial Mortgage Loans at Year End 2019. NAIC \& The Center for Insurance Policy and Research. Capital Markets Bureau Primer. [Accessed 2020, November 29]. 